\title{
Comparative Study of New Hplc And Hptlc Methods For Simultaneous Determination of Dipyrone And Camylofin Dihydrochloride Using Hyoscine Butyl Bromide As Internal Standard
}

\author{
Asmaa M. Atta ${ }^{1}$, Mohamed S. Gomaa ${ }^{2}$, Ismail Salama ${ }^{2}$, Samia M. Mostafa ${ }^{2}$ \\ ${ }^{I}$ (Medicinal Chemistry Department, Faculty Of Pharmacy/ Sinai University, Egypt) \\ ${ }^{2}$ (Medicinal Chemistry Department, Faculty Of Pharmacy/Suez Canal University, Egypt)
}

\begin{abstract}
Two new methods are developed for simultaneous determination of dipyrone (Dip) and camylofin dihydrochloride (Cam) in bulk and in pharmaceutical formulation (Spasmopyralgin $M^{\circledR}$ tablet) using hyoscine butyl bromide as internal standard (I.S.) to further increase the applicability of the methods. The first method

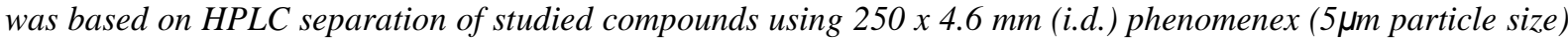
$C_{18}$ column as stationary phase and mixture of $50 \mathrm{mM}$ ammonium acetate ( $\mathrm{pH}$ adjusted to 5.3 using acetic acid) and acetonitrile as mobile phase. The second one was HPTLC method where the separation was achieved on Merck HPTLC aluminium plates of silica gel $60 F_{254}$ using acetone: methanol: acetic acid (52: 28: 20, v/v/v) as mobile phase. Comparative study was performed to argue the advantage of each method and determine which one is better for routine analysis of studied drugs.
\end{abstract}

Keywords: dipyrone, camylofin dihydrochloride, comparative study, HPLC, HPTLC and hyoscine butyl bromide.

\section{Introduction}

Dipyrone (metamizole) sodium; [(1, 5-dimethyl-3-oxo-2-phenylpyrazol-4-yl) methyl amino $]$ methanesulfonate Fig. (1) is a popular analgetic, non-opioid drug, commonly used in human and veterinary medicine. In some cases, this agent is still incorrectly classified as a non-steroidal anti-inflammatory drug (NSAID). Metamizole is a pro-drug, which spontaneously breaks down after oral administration to structurally related pyrazolone compounds [1]. Several methods have been reported for determination of dipyrone either alone or in combination with other drugs; these methods include HPLC [2-6], spectrophotometry [7-9] and RpTLC [10].

Camylofin dihydrochloride 3-methylbutyl 2-[2-(diethylamino)ethylamino]-2-phenyl acetate dihydrochloride Fig. (2) is a very powerful antispasmodic drug and recent studies have shown the efficacy of camylofin dihydrochloride in shortening the first phase of labor significantly and accelerating the rate of cervical dilation without any effect on uterine activity [11]. Literature review has shown many methods for determination of camylofin dihydrochloride which include HPLC [12-16] and HPTLC [17-19].

Hyoscine butyl bromide (1R,2R,4S,5S,7s,9S)-9-Butyl-7-\{[(2S)-3-hydroxy-2-phenylpropanoyl] oxy\}-9methyl-3-oxa-9-azoniatricyclo [3.3.1.02,4] nonane bromide Fig. (3) is a quaternary ammonium anticholinergic agent. It has antispasmodic action on the smooth muscles of the gastrointestinal, biliary, and urinary tracts [20].

Hyoscine butyl bromide is added to the studied mixture to further increase the applicability of the methods. It is combined with dipyrone in the market under the name of Buscopan Compositum ${ }^{\circledR}$ tablet and it is commonly prescribed for relieving spasm in smooth muscles of gastrointestinal, biliary, urinary tract and female genital organs. It also acts as an internal standard to increase the accuracy, reproducibility and validity of the method. Thus, simultaneous determination of these three compounds by simple and accurate analytical methods is of pharmaceutical significance.

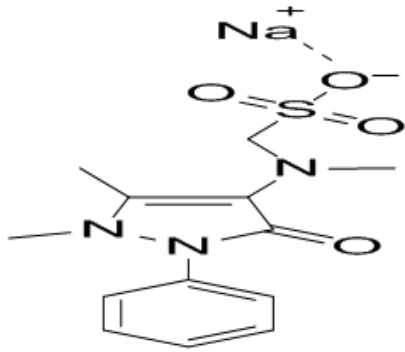

Fig. (1): structure of dipyrone

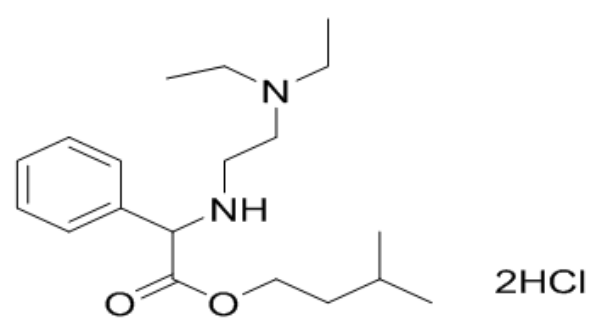

Fig. (2): structure of camylofin dihydrochloride 


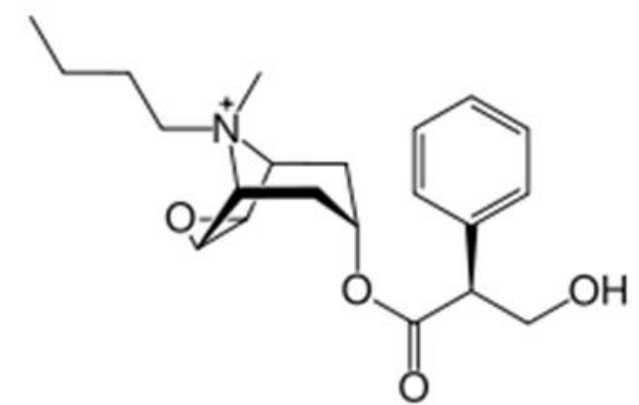

Fig. (3): structure of hyoscine butyl bromide

\subsection{Materials and reagents}

\section{Experimental}

Pharmaceutical-grade authentic standards of dipyrone and camylofin dihydrochloride were kindly supplied by EL KHAIRA pharmaceutical company, Egypt and certified to contain $100.79 \%$ and $99.08 \%$ respectively. Pharmaceutical grade of hyoscine butyl bromide was kindly supplied by EPICIO pharmaceutical company, Egypt and certified to contain $99.9 \%$.

Acetonitrile and methanol used were of HPLC grade (LAB-SCAN Analytical science, POCH, Poland). Ammonium acetate, acetone and acetic acid used were of analytical grade. All chemicals were used as received without further modification or purification.

Spasmopyralgin $\mathrm{M}^{\circledR}$ tablet manufactured by EL KHAIRA pharmaceutical company (Cairo, Egypt), (batch No. 1510051) labeled to contain $225 \mathrm{mg}$ dipyrone and $25 \mathrm{mg}$ camylofin dihydrochloride per tablet.

\subsection{Instrumental and chromatographic conditions}

The chromatographic HPLC analysis was performed via KnauerTM HPLC system [Berlin,Germany]. The whole chromatographic system was driven by EuroChrom ${ }^{\circledR}$ version 3.05 chromatography manager software [Kaneur, Germany], which also used for chromatograms acquisition and processing. The detection wavelength was set at $220 \mathrm{~nm}$ selected using a double-beam Shimadzu [Tokyo, Japan] UV-1601 PC UV-Visible spectrophotometer (10 mm optical path length matched quartz cell). The HPLC separation and quantitation were made on a $250 \times 4.6 \mathrm{~mm}$ (i.d.) phenomenex ( $5 \mu \mathrm{m}$ particle size) $\mathrm{C} 18$ column.

A gradient mobile phase system consisting of mobile phase (A) $50 \mathrm{mM}$ of ammonium acetate adjusted to $\mathrm{pH} 5.3$ using acetic acid and mobile phase (B) 100\% of acetonitrile was used. The gradient program used for the separation was as follows: from (0-6 min), $65 \%$ mobile phase (A): $35 \%$ mobile phase (B) with a flow rate of $1 \mathrm{~mL} / \mathrm{min}$ for separation of dipyrone and hyoscine butyl bromide (I.S.) then gradient up to $95 \%$ mobile phase (B) after $6 \mathrm{~min}$ with flow rate $1.5 \mathrm{~mL} / \mathrm{min}$ till $15 \mathrm{~min}$ for separation of camylofin dihydrochloride. After $15 \mathrm{~min}$ the gradient was returned to the initial condition and the analytical column was reconditioned for $5 \mathrm{~min}$.

The $\mathrm{pH}$ of the mobile phase was adjusted by cole parmer® $\mathrm{pH}$-meter. The mobile phase was filtered using phenomenexTM vacuum filtration system equipped with $0.45 \mu \mathrm{m}$ nylon membrane filter and finally degassed for $30 \mathrm{~min}$ via an ultrasonic bath and was allowed to run for $10 \mathrm{~min}$ prior each analysis.

All the determinations were performed at ambient temperature $\left(25^{\circ} \mathrm{C} \pm 1\right)$. Twenty $\mu 1$ of samples were injected using a $25 \mu 1$ Hamilton analytical syringe.

For maximal sensitivity of HPTLC method, solutions of the testing samples and standards were applied to HPTLC plates as bands rather than spots. Bands were $6 \mathrm{~mm}$ long and $5 \mu 1$ of the sample was applied to each band. The bands were separated by a distance of $10.5 \mathrm{~mm}$ apart and $10 \mathrm{~mm}$ from the bottom of the plate. The development chamber was saturated with mobile phase. The HPTLC plate was developed in ascending way using acetone: methanol: acetic acid (52: 28: 20, v/v/v) as mobile phase. After developing over a distance of 7 $\mathrm{cm}$, the HPTLC plate was air dried and scanned at $254 \mathrm{~nm}$. The scan length and width were adjusted to cover the entire band.

\subsection{Standard solutions and calibration graphs}

\subsubsection{For HPLC method}

Stock solutions of dipyrone and camylofin dihydrochloride were prepared separately by dissolving 50 $\mathrm{mg}$ of each compound in $50 \mathrm{~mL}$ methanol $(1 \mathrm{mg} / \mathrm{mL})$. Standard serial solutions were prepared by further dilutions of stock solutions with the specified mobile phase to reach the concentration range of (5-275) $\mu \mathrm{g} / \mathrm{mL}$ for dipyrone, and (7-200) $\mu \mathrm{g} / \mathrm{mL}$ for camylofin dihydrochloride. Standard solution of hyoscine butyl bromide (I.S.) was prepared by dissolving $50 \mathrm{mg}$ of hyoscine butyl bromide in $50 \mathrm{~mL}$ methanol.

Triplicate $20 \mu \mathrm{L}$ injections were made for each concentration and chromatographed under the specified chromatographic conditions described previously. The peak area ratio (peak area of dipyrone or camylofin 
dihydrochloride / peak area of hyoscine butyl bromide) were plotted against corresponding concentrations. Linear relationships were obtained.

\subsubsection{For HPTLC method}

Stock solutions in concentration $(16 \mathrm{mg} / \mathrm{mL})$ for dipyrone, and $(10 \mathrm{mg} / \mathrm{mL})$ for camylofin dihydrochloride were prepared in methanol.

The standard solutions were prepared by further dilutions of stock solutions with methanol to reach the concentration range of (5-80 $\mathrm{g}$ /band) for dipyrone, and (3-50 $\mu \mathrm{g} / \mathrm{band})$ for camylofin dihydrochloride. Standard solution of hyoscine butl bromide (I.S.) was prepared in concentration of $(7 \mathrm{mg} / \mathrm{mL})$.

Laboratory prepared mixtures were prepared by mixing appropriate concentration of the compounds pure powder form in $10 \mathrm{~mL}$ volumetric flask and completing the volume with methanol.

Five microlitres of each standard solution were applied to the HPTLC plates. Triplicate applications were made for each solution. The plates were developed using previously described mobile phase. The calibration curves were constructed relating the integrated peak area ratio to the corresponding concentration as ( $\mu \mathrm{g} / \mathrm{band})$.

\subsection{Pharmaceutical formulations Preparations 2.4.1 For HPLC method}

Ten tablets (Spasmopyralgin $\mathbf{M}^{\circledR}$ ) were accurately weighed and finally powdered. A portion of the powder equivalent to $225 \mathrm{mg}$ of dipyrone and $25 \mathrm{mg}$ of camylofin dihydrochloride was transferred to $50 \mathrm{~mL}$ volumetric flask, dissolved in $30 \mathrm{~mL}$ methanol using ultrasonic bath for $30 \mathrm{~min}$ and cooled to room temperature. The solution was diluted to volume with the same solvent and then filtered through $0.45 \mu \mathrm{m}$ membrane filters (Millipore, Milford, MA). Further dilutions were carried out with the mobile phase to reach calibration range of each compound and $10 \mu \mathrm{g} / \mathrm{mL}$ of hyoscine butyl bromide solution was added. The prepared sample solutions were chromatographed using the HPLC conditions described above and the concentration of dipyrone and camylofin dihydrochloride were calculated.

\subsubsection{For HPTLC method}

Five separate portions of the finely powdered form of spasmopyralgin tablet were accurately weighed according to the linearity range and the percentage of each compound in the tablet. Each portion of weighed powder was transferred to $10 \mathrm{~mL}$ volumetric flask, dissolved in about $5 \mathrm{~mL}$ methanol using ultrasonic bath for $30 \mathrm{~min}$, cooled to room temperature and $7 \mu \mathrm{g} / \mathrm{band}$ of hyoscine butyl bromide solution (I.S.) was added. The solution was diluted to the volume with the same solvent and then filtered through $0.45 \mu \mathrm{m}$ membrane filter (Millipore, Milford, MA). Five microliters of each sample solution were applied to the HPTLC plates. The plates were developed in the previously described chromatographic conditions. The concentrations of each compound were determined by substituting in the regression equation.

\subsection{HPLC method}

\section{Results and discussion}

A reliable, sensitive and accurate RP-HPLC method is developed for simultaneous determination of dipyrone, and camylofin dihydrochloride using hyoscine butyl bromide as internal standard in bulk and the method is applied successfully to the pharmaceutical preparations containing these compounds.

To obtain the best chromatographic conditions, different parameters such as the percentage of organic modifier of mobile phase, $\mathrm{pH}$ of buffer and flow rate were studied:

\section{The effect of percentage of organic modifier}

The percentage of organic modifier has a critical effect on the separation of the studied compounds. It was found that when the proportion of organic modifier (acetonitrile) was 50\%, the resolution between dipyrone and hyoscine butyl bromide (I.S.) was poor and camylofin dihydrochloride was retained. By increasing the proportion of acetonitrile more than $50 \%$, there was an overlapping between dipyrone and hyoscine butyl bromide peaks and camylofin dihydrochloride was less retained with better peak shape. By decreasing proportion of acetonitrile less than $50 \%$, the resolution between dipyrone and hyoscine butyl bromide was reasonable but camylofin dihydrochloride was highly retained $(\sim 26.33 \mathrm{~min})$ with excessive peak tailing.

Thus we decided to use gradient elution programme in order to optimize the chromatographic separation between the three studied compounds.

A possible explanation for that could be attributed to chemical structure of camylofin dihydrochloride which contains branched aliphatic chain that can forms hydrophobic interaction with reversed phase silica and thus gradient elution is necessary for its separation when combined with polar compounds such as dipyrone. 
A calculated $\log \mathrm{P}$ for camylofin using chem axon software was found to be 3.7 while $\log \mathrm{P}$ of unionized species for dipyrone and hyoscine butyl bromide were -0.07 and -3.27 respectively demonstrated further the hydrophobic nature of camylofin dihydrochloride compared to dipyrone and hyoscine butyl bromide.

\section{The effect of $\mathrm{pH}$ of buffer}

At $\mathrm{pH}$ (4.6-5.6), good resolution with good peak shapes was obtained. However, $\mathrm{pH} 5.3$ was chosen as optimum $\mathrm{pH}$ as best resolution with better peak shapes and reasonable run time were obtained.

The effect of flow rate:

The proposed HPLC method was performed at flow rate $1 \mathrm{ml} / \mathrm{min}$ at the beginning of run from (zero to $6 \mathrm{~min}$ ) and then increased gradually after $6 \mathrm{~min}$ to $1.5 \mathrm{ml} / \mathrm{min}$ till the end of the run. It was found that increasing the flow rate at the beginning of run $(>1 \mathrm{~mL} / \mathrm{min})$ lead to rapid elution of dipyrone and interference of its peak with solvent front but at flow rate less than $1 \mathrm{~mL} / \mathrm{min}$, peaks were dispersed at the cost of run time. Flow rate 1.5 $\mathrm{ml} / \mathrm{min}$ was the best one for elution of camylofin dihydrochloride as by decreasing it excessive tailing was obtained.

According to above investigation, the best chromatographic separation was obtained by using mobile phase consisting of acetonitrile and $50 \mathrm{mM}$ ammonium acetate $(\mathrm{pH} 5.3)$ in ratio of $(35: 65, \mathrm{v} / \mathrm{v})$ with flow rate 1 $\mathrm{mL} / \mathrm{min}$ for $6 \mathrm{~min}$ and then increase the proportion of acetonitrile to $95 \%$ with flow rate $1.5 \mathrm{~mL} / \mathrm{min}$ till $15 \mathrm{~min}$.

The specificity of the method is illustrated in (Fig. 4) where complete resolution of the studied compounds was noticed. The average retention time \pm standard deviation for dipyrone, hyoscine butyl bromide (I.S.) and camylofin dihydrochloride were $3.472 \pm 0.03,4.87 \pm 0.02$ and $8.75 \pm 0.1$ respectively, for five replicates. The characteristic parameters of the linear regression equations of these compounds are shown in table (2).

\subsection{HPTLC method}

An accurate, precise and reproducible HPTLC method is developed for simultaneous determination of dipyrone, and camylofin dihydrochloride using hyoscine butyl bromide as internal standard in bulk and in their pharmaceutical formulations.

Several preliminary expirements were performed in order to optimize the HPTLC chromatographic conditions. First, mixtures of different proportions of ethyl acetate and hexane were used as mobile solvent but no separation was obtained. Then Mixture of methanol and acetic acid (mobile solvent with higher eluting power) in ratio of (80:20) was used, the bands of studied compounds were differentiated but with bad resolution between camylofin dihdrochloride and hyoscine butyl bromide (I.S.). By addition of acetone and decreasing the proportion of methanol, better resolution with better bands shape were obtained. Greatest differences between Rf values of studied compounds with best bands shape were achieved by using mobile solvent consisting of acetone: methanol: acetic acid in the ratio of (52:28: 20, v/v/v). The wavelength of scanning was chosen to be $254 \mathrm{~nm}$.

The specificity of the HPTLC method is illustrated in (Fig. 5) where complete separation of the studied compounds was noticed. The Rf values of the studied compounds were ( 0.17 for hyoscine butyl bromide (I.S.), 0.45 for camylofin dihydrochloride and 0.63 for dipyrone) with minimum tailing.

The characteristic parameters of the linear regression equations of these compounds are shown in table (3).

\subsection{Linearity and range}

\section{Validation Of The Methods}

The linearity of a test procedure is its ability (within a given range) to obtain test results proportional to the concentration of analyte in the sample. The linearity of the HPLC and HPTLC methods was evaluated by analyzing a series of different concentrations of each drug, hyoscine butyl bromide was used as (I.S.). In this study ten concentrations were chosen, ranging between 5-275 $\mu \mathrm{g} / \mathrm{mL}$ for dipyrone and 7-200 $\mu \mathrm{g} / \mathrm{mL}$ for camylofin dihydrochloride using HPLC method. Six concentrations were chosen, ranging between 5-80 $\mu \mathrm{g} / \mathrm{band}$ for dipyrone and 3-50 $\mu \mathrm{g} / \mathrm{band}$ for camylofin dihydrochloride using HPTLC method.

Each concentration was repeated three times; in order to provide information on the variation in peak area values between samples of same concentration. The mean value of the peak area ratio was taken for construction the calibration curve. The linearity of the calibration graphs was validated by the high value of the correlation coefficient $(r=0.999)$. Characteristic parameters for the regression equations of the HPLC and HPTLC methods obtained by least square treatment of the results were shown in (tables $2 \& 3$ ).

\subsection{Precision}

The precision of the methods, expressed as coefficient of variation (CV \%), was determined by analysis of three different concentrations within linearity range.

Intra-day precision (repeatability) of HPLC and HPTLC methods was assessed from the results of three replicate analyses in the same day. Inter-day precision of the HPLC and HPTLC methods was determined by 
analysis of three samples in three consecutive days. Each sample was injected in triplicates and CV\% values were calculated and found to be less than 2 showing good precision for the methods as listed in tables (4\&5).

\subsection{Limit of detection and limit of qantitation}

The limit of detection (LOD) and limit of quantification (LOQ) were determined according to the current ICH guidelines as the ratio of 3.3 and 10 standard deviations of the blank respectively; against the slope of the calibration line [21]. The theoretical values of LOD and LOQ were assessed practically and given in tables $(2 \& 3)$.

\subsection{Accuracy}

The accuracy of the proposed methods was determined by standard addition technique which was applied to Spasmopyralgin ${ }^{\circledR}$ tablets to study the interference of excipients in pharmaceutical formulations. Sample solutions were spiked with standard drug solutions, the mean percentage recoveries and their standard deviation for six replicates were calculated. The results showed the good accuracy and the excipients in the pharmaceutical formulations did not interfere in the analysis by the proposed methods (tables $6 \& 7$ ).

\subsection{Selectivity}

Selectivity of the proposed methods was performed by preparing eight laboratory-prepared mixtures of the studied compounds at various concentrations within their linearity range. The laboratory-prepared mixtures were analyzed according to the previous procedures described under the proposed methods. Satisfactory results were obtained as listed in tables (8\&9) indicating the high selectivity of the proposed methods for simultaneous determination of studied compounds.

\subsection{Robustness}

Robustness of analytical method is defined as the capacity of the method to remains unaffected by small but deliberate variations introduced into the method critical parameters. Variation the organic strength of the mobile phase by $\pm 1 \%$ and the $\mathrm{pH}$ of the $50 \mathrm{mM}$ ammonium acetate of the mobile phase by \pm 0.2 units did not have significant effect on chromatographic resolution in HPLC method. Variation the wavelength of detection by \pm 2 did not have significant effect on chromatographic resolution in HPLC and HPTLC methods.

Only one parameter was changed at a time and analysis was performed according to the previous procedures. The obtained results indicated the robustness of the proposed HPLC and HPTLC methods as listed in tables $(14 \& 15)$.

\subsection{System suitability test}

System suitability tests (SST) are commonly used to verify resolution, column efficiency, and repeatability of a chromatographic system to ensure its adequacy for a particular analysis. The tests are based on the concept that the equipment, electronics, analytical operations and samples to be analyzed constitute an integral system that can be evaluated as a whole. Resolution (Rs) is a measure of the degree of separation between adjacent peaks. A value of 1.5 for resolution implies a complete separation of the two compounds [22]. Values of capacity factor $(\mathrm{k} /)$, tailing factor, selectivity factor, resolution factor and theoretical plates were calculated for studied compounds and found to be acceptable as listed in table (1).

\subsection{Analytical solutions stability}

The solutions were stored in tightly capped volumetric flasks and wrapped with aluminum foil under reduced light conditions. It was found that hyoscine butyl bromide (I.S.) and camylofin dihydrochloride analytical solutions in methanol exhibited no changes for at least 2 weeks when stored refrigerated at $4^{\circ} \mathrm{C}$ and for 24 hours when kept at room temperature. Dipyrone analytical solution in methanol exhibited no changes for 7 days when stored refrigerated at $4^{\circ} \mathrm{C}$ and for 12 hours when kept at room temperature. Solutions of the studied compounds in the mobile phase exhibited no changes for 6 hours when kept at room temperature.

\subsection{Analysis of pharmaceutical products}

The validated HPLC and HPTLC methods were applied for the determination of (dipyrone and camylofin dihydrochloride) in pharmaceutical preparation using Spasmopyralgin ${ }^{\circledR}$ tablets (Fig. 6\&7).

Three replicate determinations were performed at each concentration level. Satisfactory results were obtained for each compound in good agreement with label claims (tables 10\&11).

The obtained results were compared statistically by Student's $t$-test (for accuracy) and variance ratio F-test (for repeatability) with the published method [6 \& 14]. The results showed that the calculated $\mathrm{t}$ and $\mathrm{F}$ values were smaller than the critical values at $95 \%$ confidence limit indicating that there was no significant difference between the proposed and published methods (tables 12\&13). 
Even if we choose to use the method for the simultaneous determination of hyosine and dipyrone, the developed chromatographic methods was proven not significantly different from the reference methods [2 \& 10] in term of sensitivity, accuracy and run time, however our methods offer more application for the determination of a third component that is combined with dipyrone in different pharmaceutical products

\section{Conclusion}

The proposed HPLC and HPTLC methods provide simple, accurate and reproducible quantitative analysis for the simultaneous determination of pharmaceutical products containing dipyrone, camylofin dihydrochloride using hyoscine butyl bromide as internal standard without any interference from excipients.

Our study showed that both chromatographic methods are suitable for routine analysis of the studied compounds in their pharmaceutical preparations, however, the HPTLC method is relatively simpler, rapid, and economic compared to the HPLC method.

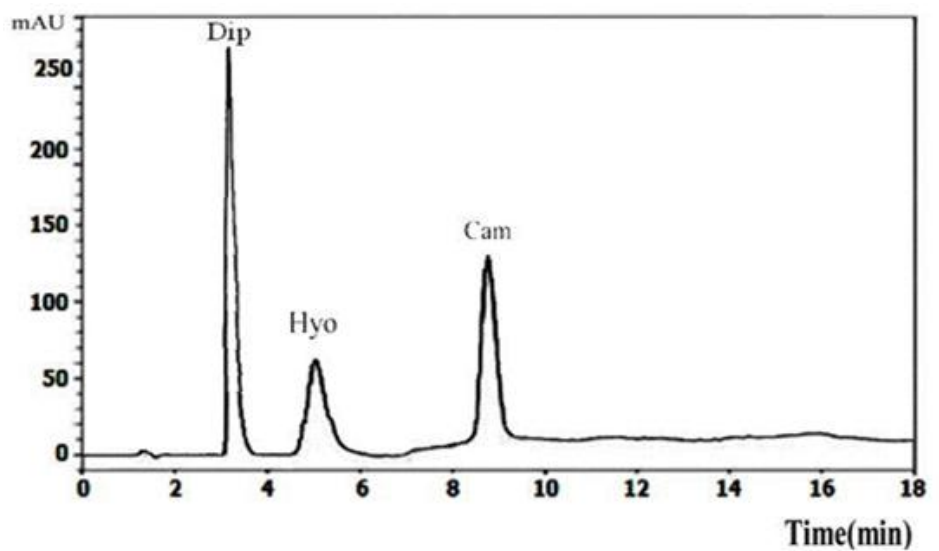

Fig. 4: HPLC chromatogram of (Dip) dipyrone $(20 \mu \mathrm{g} / \mathrm{mL})$, (Cam) camylofin dihydrochloride $(15 \mu \mathrm{g} / \mathrm{mL})$ and (Hyo) hyoscine butyl bromide (I.S.) $(10 \mu \mathrm{g} / \mathrm{mL})$.

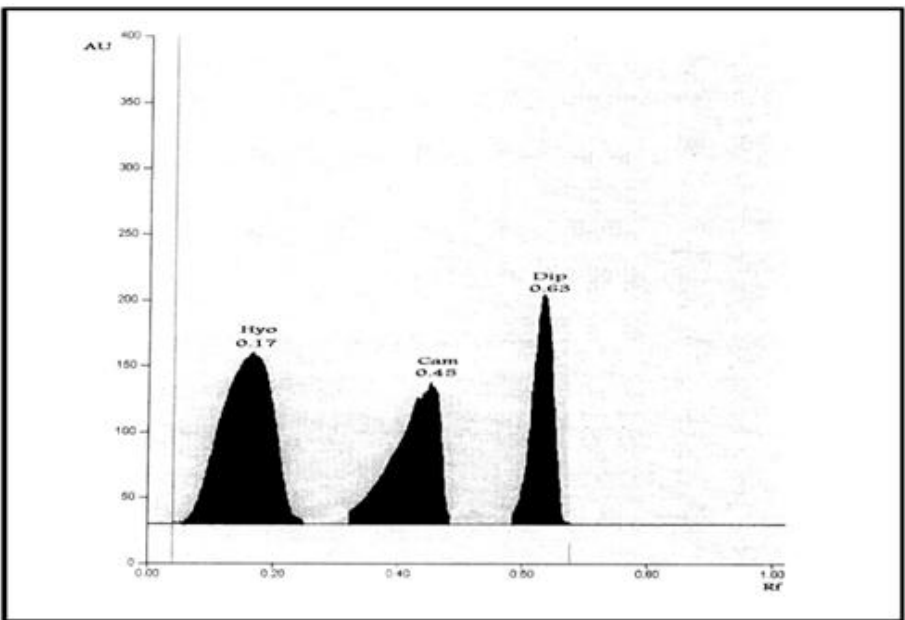

Fig. 5: HPTLC chromatogram of (Dip) dipyrone (30 $\mu \mathrm{g} / \mathrm{band})$, (Cam) camylofin dihydrochloride (15 $\mu \mathrm{g} / \mathrm{band})$ and (Hyo) hyoscine butyl bromide (I.S.) $(25 \mu \mathrm{g} / \mathrm{band})$. 


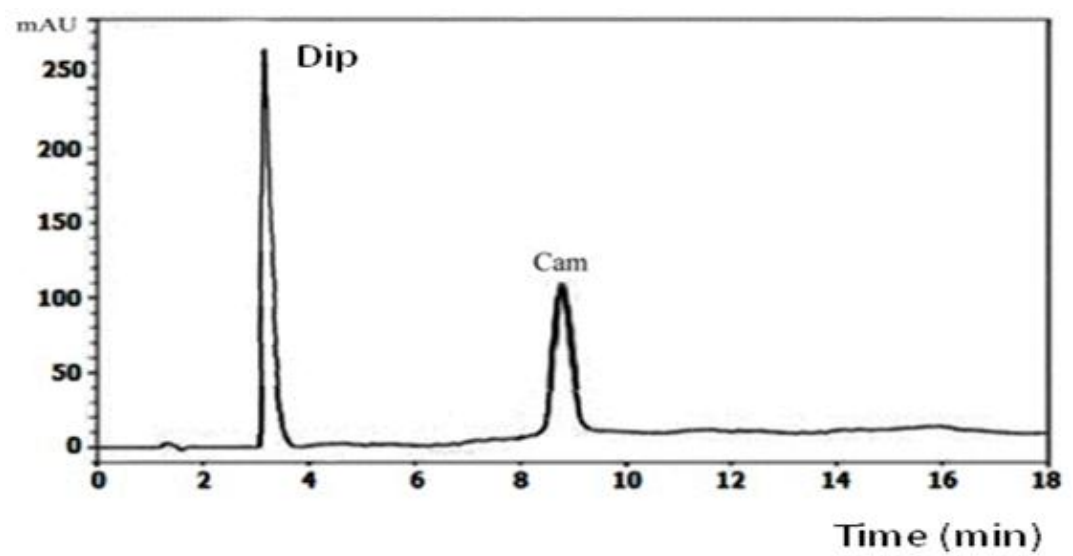

Fig. 6 : typical HPLC chromatogram of spasmopyralgin ${ }^{\circledR}$ tablet.

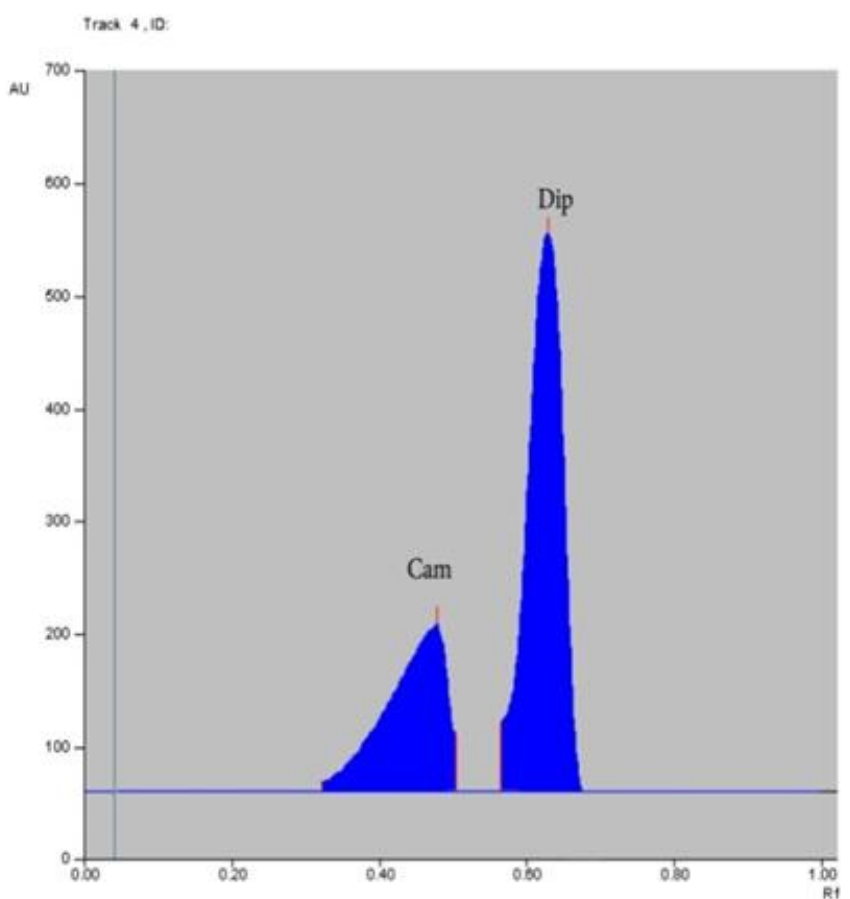

Fig. 7: Typical HPTLC chromatogram of spasmopyralgin ${ }^{\circledR}$ tablet.

Table 1: The system suitability test results of the developed HPLC method for determination of dipyrone , hyoscine butyl bromide and camylofin dihydrochloride.

\begin{tabular}{|l|l|l|l|l|l|l|l|}
\hline Compound & tR $(\min ) \mathrm{a}$ & $(\mathrm{k} /)$ & $(\alpha) \mathrm{b}$ & $(\mathrm{Rs}) \mathrm{b}$ & $\mathrm{T}$ & $\%$ RSD & $\mathrm{N}$ \\
\hline Dipyrone & 3.47 & 1.17 & $1.74(\mathrm{a} 1)$ & $3.5(\mathrm{~b} 1)$ & 1.11 & 0.86 & 6670.66 \\
\hline Hyoscine (I.S.) & 4.87 & 2.04 & $2.19(\mathrm{a} 2)$ & $9.12(\mathrm{~b} 2)$ & 1.25 & 0.41 & 3284.79 \\
\hline Camylofin & 8.75 & 4.47 & & & 1.13 & 1.14 & 10603.91 \\
\hline
\end{tabular}

Where $t_{R}$ is retention time, $k^{\prime}$ is capacity factor, $\alpha$ is selectivity, $R_{s}$ is resolution, $T$ is tailing factor, RSD\% is relative standard deviation of retention time and $\mathrm{N}$ is number of theoretical plates.

a: The retention time of unretained peak is $1.6 \mathrm{~min}$.

$\mathrm{b}: \mathrm{a}_{1}, \mathrm{~b}_{1}$ : are $\alpha$ and $\mathrm{R}_{\mathrm{s}}$ calculated for dipyrone and hyoscine butyl bromide.

$\mathrm{a}_{2}, \mathrm{~b}_{2}$ : are $\mathrm{a}$ and $\mathrm{R}_{\mathrm{s}}$ calculated for hyoscine butyl bromide and camylofin dihydrochloride.

Table 2: Characteristic parameters of the calibration equations of the proposed HPLC method for simultaneous determination of dipyrone and camylofin dihydrochloride.

\begin{tabular}{|l|c|c|}
\hline \multicolumn{1}{|c|}{ Parameter } & Dipyrone & Camylofin dihdrochloride \\
\hline Linearity range $(\boldsymbol{\mu g} / \mathbf{m L})$ & $5-275$ & $7-200$ \\
\hline Limit of detection $(\boldsymbol{\mu g} / \mathbf{m L})$ & $12.41 \times 10^{-1}$ & $94.21 \times 10^{-2}$ \\
\hline Limit of quantitation $(\boldsymbol{\mu g} / \mathbf{m L})$ & $37.62 \times 10^{-1}$ & $28.55 \times 10^{-1}$ \\
\hline
\end{tabular}


Comparative Study of New Hplc And Hptlc Methods For Simultaneous Determination of ....

\begin{tabular}{|c|c|c|}
\hline Regression equation $(\mathbf{Y})^{\mathrm{a}}$ : & $\mathrm{Y}=0.9750 \mathrm{C}-0.2294$ & $\mathrm{Y}=0.2713 \mathrm{C}-0.3108$ \\
\hline Slope (b) & 0.9750 & 0.2713 \\
\hline Standard deviation of slope $\left(S_{b}\right)$ & 0.0025 & 0.0007 \\
\hline Relative standard deviation of the slope $(\%)$ & 0.0022 & 0.0008 \\
\hline Confidence limit of slope $^{b}$ & $0.9732-0.9768$ & $0.2708-0.2718$ \\
\hline Intercept (a) & -0.2294 & -0.3108 \\
\hline Standard deviation of intercept $\left(\mathrm{S}_{\mathrm{a}}\right)$ & 0.3668 & 0.0775 \\
\hline Relative standard deviation of the intercept (\%) & 0.3246 & 0.0854 \\
\hline Confidence limit of the intercept $^{b}$ & $-0.4969-0.0381$ & $-0.3673-(-0.2543)$ \\
\hline Correlation coefficient $(\mathbf{r})$ & 0.9999 & 0.9999 \\
\hline
\end{tabular}

$\mathrm{Y}^{\mathrm{a}}=\mathrm{a}+\mathrm{bC}$, where $\mathrm{C}$ is the concentration of compound $(\mu \mathrm{g} / \mathrm{mL})$ and $\mathrm{Y}$ is the peak area.

b $95 \%$ confidence limit

Table 3: Characteristic parameters of the calibration equations of the proposed HPTLC method for simultaneous determination of dipyrone and camylofin dihydrochloride.

\begin{tabular}{|l|c|c|}
\hline \multicolumn{1}{|c|}{ Parameter } & Dipyrone & Camylofin dihydrochloride \\
\hline Linearity range $(\boldsymbol{\mu g} / \mathbf{b a n d})$ & $5-80$ & $3-50$ \\
\hline Limit of detection $(\boldsymbol{\mu g} / \mathbf{b a n d})$ & $48.35 \times 10^{-2}$ & $83.18 \times 10^{-2}$ \\
\hline Limit of quantitation $(\boldsymbol{\mu g} / \mathbf{b a n d})$ & $14.65 \times 10^{-1}$ & $25.20 \times 10^{-1}$ \\
\hline Regression equation $(\mathbf{Y})^{\mathbf{a}} \mathbf{:}$ & $\mathrm{Y}=4.1185 \mathrm{C}-0.3789$ & $\mathrm{Y}=7.4234 \mathrm{C}+2.4443$ \\
\hline Slope $(\mathbf{b})$ & 4.1185 & 7.4234 \\
\hline Standard deviation of slope $\left(\mathbf{S}_{\mathbf{b}}\right)$ & 0.0150 & 0.0627 \\
\hline Relative standard deviation of the slope (\%) & 0.0502 & 0.2544 \\
\hline Confidence limit of slope $\mathbf{b}^{\mathbf{b}}$ & $4.1015-4.1356$ & $7.3522-7.4945$ \\
\hline Intercept $(\mathbf{a})$ & -0.3789 & 2.4443 \\
\hline Standard deviation of intercept $\left.\mathbf{( S}_{\mathbf{a}}\right)$ & 0.6035 & 1.8712 \\
\hline Relative standard deviation of the intercept $\mathbf{( \% )}$ & 2.0116 & 7.5861 \\
\hline Confidence limit of the intercept $\mathbf{t}^{\mathbf{b}}$ & $-1.0629-0.3052$ & $0.3233-4.5654$ \\
\hline Correlation coefficient $(\mathbf{r})$ & 0.9999 & 0.9999 \\
\hline
\end{tabular}

$\mathrm{Y}^{\mathrm{a}}=\mathrm{a}+\mathrm{bC}$, where $\mathrm{C}$ is the concentration of compound $(\mu \mathrm{g} / \mathrm{band})$ and $\mathrm{Y}$ is the peak area.

b $95 \%$ confidence limit

Table 4: Results of intra-day and inter-day precision for dipyrone and camylofin dihydrochloride standard solutions by proposed HPLC method.

\begin{tabular}{|c|c|c|c|c|c|c|c|}
\hline \multirow[b]{2}{*}{ Compound } & \multirow[b]{2}{*}{$\begin{array}{l}\text { Conc. } \\
\text { taken } \\
(\mu \mathrm{g} / \mathrm{mL})\end{array}$} & \multicolumn{3}{|c|}{ Intra-day precision } & \multicolumn{3}{|c|}{ Inter-day precision } \\
\hline & & $\begin{array}{l}\text { Conc. } \\
\text { found } \\
(\mu \mathrm{g} / \mathrm{mL})\end{array}$ & $\begin{array}{c}\text { Recovery }{ }^{\mathrm{a}} \% \pm \\
\text { SD }\end{array}$ & CV\% & $\begin{array}{l}\text { Conc. } \\
\text { found } \\
(\mu \mathrm{g} / \mathrm{mL})\end{array}$ & $\begin{array}{c}\text { Recovery }^{\mathrm{b}} \% \\
\pm \text { SD }\end{array}$ & $\begin{array}{c}\text { CV } \\
\%\end{array}$ \\
\hline \multirow[t]{3}{*}{ Dip } & 30 & 30.10 & $100.33 \pm 0.67$ & 0.67 & 29.94 & $99.80 \pm 0.60$ & 0.60 \\
\hline & 50 & 49.99 & $99.98 \pm 0.20$ & 0.20 & 50.06 & $100.13 \pm 0.36$ & 0.36 \\
\hline & 80 & 80.09 & $100.12 \pm 0.24$ & 0.24 & 80.02 & $100.03 \pm 0.20$ & 0.20 \\
\hline \multirow[t]{3}{*}{ Cam } & 50 & 49.96 & $99.92 \pm 0.58$ & 0.58 & 49.90 & $99.80 \pm 0.90$ & 0.90 \\
\hline & 70 & 70.31 & $100.45 \pm 0.76$ & 0.76 & 70.23 & $100.33 \pm 0.31$ & 0.31 \\
\hline & 100 & 99.92 & $99.92 \pm 0.18$ & 0.18 & 99.77 & $99.77 \pm 0.32$ & 0.32 \\
\hline
\end{tabular}

${ }^{\mathrm{a}}$ Mean and SD for three determinations.

${ }^{b}$ Mean and SD for three constitutive days.

Table 5: Results of intra-day and inter-day precision for dipyrone and camylofin dihydrochloride standard solutions by proposed HPTLC method.

\begin{tabular}{|c|c|c|c|c|c|c|c|}
\hline \multirow[b]{2}{*}{ Compound } & \multirow[b]{2}{*}{$\begin{array}{c}\text { Conc. } \\
\text { taken } \\
\text { ( } \mu \mathrm{g} / \mathrm{band})\end{array}$} & \multicolumn{3}{|c|}{ Intra-day precision } & \multicolumn{3}{|c|}{ Inter-day precision } \\
\hline & & $\begin{array}{c}\text { Conc. } \\
\text { found } \\
\text { ( } \mu \mathrm{g} / \mathrm{band})\end{array}$ & Recovery $^{\mathrm{a}} \% \pm \mathrm{SD}$ & CV\% & $\begin{array}{c}\text { Conc. } \\
\text { found } \\
\text { ( } \mu \mathrm{g} / \mathrm{band})\end{array}$ & $\begin{array}{c}\text { Recovery }^{\mathrm{b}} \% \\
\pm \text { SD }\end{array}$ & $\begin{array}{c}\mathrm{CV} \\
\%\end{array}$ \\
\hline \multirow[t]{3}{*}{ Dip } & 5 & 5.06 & $101.13 \pm 1.60$ & 1.58 & 5.12 & $102.47 \pm 1.8$ & 1.76 \\
\hline & 7 & 7.11 & $101.57 \pm 1.57$ & 1.55 & 6.99 & $99.91 \pm 1.71$ & 1.71 \\
\hline & 10 & 9.91 & $99.07 \pm 1.80$ & 1.82 & 10.16 & $101.63 \pm 1.8$ & 1.77 \\
\hline \multirow[t]{3}{*}{ Cam } & 3 & 2.99 & $99.89 \pm 1.01$ & 1.01 & 2.97 & $99.11 \pm 1.93$ & 1.95 \\
\hline & 10 & 10.08 & $100.83 \pm 1.30$ & 1.29 & 9.98 & $99.77 \pm 1.98$ & 1.98 \\
\hline & 30 & 30.24 & $100.80 \pm 1.5$ & 1.49 & 30.15 & $100.5 \pm 1.33$ & 1.32 \\
\hline
\end{tabular}

${ }^{\mathrm{a}} \mathrm{Mean}$ and SD for three determinations.

${ }^{\mathrm{b}}$ Mean and SD for three constitutive days. 
Comparative Study of New Hplc And Hptlc Methods For Simultaneous Determination of ....

Table 6: Results of accuracy for assay of dipyrone and camylofin dihydrochloride by standard addition technique using the proposed HPLC method.

\begin{tabular}{|c|c|c|c|c|c|c|c|}
\hline \multicolumn{4}{|c|}{ Dipyrone } & \multicolumn{4}{|c|}{ Camylofin dihydrochloride } \\
\hline $\begin{array}{l}\text { Claimed } \\
\text { conc. } \\
(\mu \mathrm{g} / \mathrm{mL})\end{array}$ & $\begin{array}{l}\text { Conc. of } \\
\text { standard } \\
\text { added } \\
(\mu \mathrm{g} / \mathrm{mL})\end{array}$ & $\begin{array}{c}\text { Conc. } \\
\text { found } \\
(\mu \mathrm{g} / \mathrm{mL})\end{array}$ & $\begin{array}{c}\text { Recovery } \\
\%\end{array}$ & $\begin{array}{c}\text { Claimed conc. } \\
(\mu \mathrm{g} / \mathrm{mL})\end{array}$ & $\begin{array}{l}\text { Conc. of } \\
\text { standard } \\
\text { added } \\
(\mu \mathrm{g} / \mathrm{mL})\end{array}$ & $\begin{array}{l}\text { Conc. found } \\
(\mu \mathrm{g} / \mathrm{mL})\end{array}$ & $\begin{array}{c}\text { Recovery } \\
\%\end{array}$ \\
\hline 90 & 10 & 100.02 & 100.17 & 10 & 5 & 14.95 & 99.06 \\
\hline 90 & 15 & 104.97 & 99.82 & 10 & 7 & 17.17 & 102.44 \\
\hline 90 & 20 & 109.83 & 99.17 & 10 & 9 & 19.16 & 101.76 \\
\hline 90 & 25 & 115.24 & 100.95 & 10 & 11 & 20.92 & 99.29 \\
\hline 90 & 30 & 119.44 & 98.14 & 10 & 13 & 23.13 & 100.97 \\
\hline 90 & 35 & 125.54 & 101.53 & 10 & 15 & 25.54 & 103.60 \\
\hline \multicolumn{3}{|c|}{ Mean recovery \% } & 99.96 & \multicolumn{3}{|c|}{ Mean recovery \% } & 101.19 \\
\hline \multicolumn{3}{|c|}{ SD } & 1.22 & \multicolumn{3}{|c|}{ SD } & 1.78 \\
\hline
\end{tabular}

Table 7: Results of accuracy for assay of dipyrone and camylofin dihydrochloride by standard addition technique using the proposed HPTLC method.

\begin{tabular}{|c|c|c|c|c|c|c|c|}
\hline \multicolumn{4}{|c|}{ Dipyrone } & \multicolumn{4}{|c|}{ Camylofin dihydrochloride } \\
\hline $\begin{array}{l}\text { Claimed conc. } \\
\text { ( } \mu \mathrm{g} / \mathrm{band})\end{array}$ & $\begin{array}{c}\text { Conc. of } \\
\text { standard } \\
\text { added } \\
(\mu \mathrm{g} / \mathrm{band})\end{array}$ & $\begin{array}{c}\text { Conc. found } \\
\text { ( } \mu \mathrm{g} / \mathrm{b} \text { and })\end{array}$ & $\begin{array}{c}\text { Recovery } \\
\%\end{array}$ & $\begin{array}{l}\text { Claimed } \\
\text { conc. } \\
(\mu \mathrm{g} / \mathrm{band})\end{array}$ & $\begin{array}{c}\text { Conc. of } \\
\text { standard added } \\
(\mu \mathrm{g} / \mathrm{band})\end{array}$ & $\begin{array}{l}\text { Conc. found } \\
\text { ( } \mu \mathrm{g} / \mathrm{band})\end{array}$ & $\begin{array}{c}\text { Recover } \\
\mathbf{y} \\
\%\end{array}$ \\
\hline 27 & 3 & 30.03 & 100.90 & 3 & 3 & 6.01 & 100.33 \\
\hline 27 & 5 & 32.10 & 102.08 & 3 & 5 & 7.98 & 99.50 \\
\hline 27 & 10 & 36.91 & 99.06 & 3 & 7 & 9.95 & 99.27 \\
\hline 27 & 15 & 42.09 & 100.64 & 3 & 9 & 11.82 & 97.98 \\
\hline 27 & 20 & 47.02 & 100.11 & 3 & 11 & 13.94 & 99.41 \\
\hline 27 & 25 & 52.17 & 100.69 & 3 & 15 & 17.95 & 99.67 \\
\hline \multicolumn{3}{|c|}{ Mean recovery \% } & 100.58 & \multicolumn{3}{|c|}{ Mean recovery \% } & 99.36 \\
\hline \multicolumn{3}{|c|}{ SD } & 0.99 & \multicolumn{3}{|c|}{ SD } & 0.77 \\
\hline
\end{tabular}

Table 8: Results of the selectivity of dipyrone and camylofin dihydrochloride in laboratory prepared mixtures using the proposed HPLC method.

\begin{tabular}{|c|c|c|c|c|}
\hline \multirow{2}{*}{ No. } & \multicolumn{2}{|c|}{ Concentration $(\boldsymbol{\mu g} / \mathbf{m L})$} & \multicolumn{2}{c|}{ Recovery \% } \\
\cline { 2 - 5 } & Dipyrone & $\begin{array}{c}\text { Camylofin } \\
\text { dihydrochloride }\end{array}$ & Dipyrone & Camylofin dihydrochloride \\
\hline $\mathbf{1}$ & 63 & 7 & 101.8 & 98.98 \\
\hline $\mathbf{2}$ & 81 & 9 & 99.9 & 99.88 \\
\hline $\mathbf{3}$ & 90 & 10 & 99.27 & 99.76 \\
\hline $\mathbf{4}$ & 108 & 12 & 100.5 & 99.59 \\
\hline $\mathbf{5}$ & 135 & 15 & 99.96 & 100.14 \\
\hline $\mathbf{6}$ & 180 & 20 & 99.59 & 109.82 \\
\hline $\mathbf{7}$ & 225 & 25 & 100.25 & 99.42 \\
\hline $\mathbf{8}$ & 270 & 30 & 100.03 & 0.57 \\
\hline
\end{tabular}

Table 9 : Results of the selectivity of dipyrone and camylofin dihydrochloride in laboratory prepared mixtures using the proposed HPTLC method.

\begin{tabular}{|c|c|c|c|c|}
\hline \multirow{2}{*}{ No. } & \multicolumn{2}{|c|}{ Concentration $(\boldsymbol{\mu g} / \mathbf{b a n d})$} & \multicolumn{2}{c|}{ Recovery \% } \\
\cline { 2 - 5 } & Dipyrone & Camylofin dihydrochloride & Dipyrone & Camylofin dihydrochloride \\
\hline $\mathbf{1}$ & 27 & 3 & 99.5 & 100.33 \\
\hline $\mathbf{2}$ & 31.5 & 3.5 & 100.4 & 99.95 \\
\hline $\mathbf{3}$ & 36 & 4 & 99.75 & 100.53 \\
\hline $\mathbf{4}$ & 40.5 & 4.5 & 101.6 & 100.58 \\
\hline $\mathbf{5}$ & 45 & 5 & 101.83 & 101.22 \\
\hline $\mathbf{6}$ & 49.5 & 5.5 & 103 & 98 \\
\hline $\mathbf{7}$ & 54 & 6 & 101.12 & 101.67 \\
\hline $\mathbf{8}$ & 58.5 & 6.5 & 98.56 & 100.21 \\
\hline \multicolumn{2}{|r|}{ Mean recovery \% } & 100.72 & 1.14 \\
\hline
\end{tabular}


Comparative Study of New Hplc And Hptlc Methods For Simultaneous Determination of ....

Table 10: Determination of dipyrone and camylofin dihydrochloride in pharmaceutical formulation (Spasmopyralgin $\mathrm{M}^{\circledR}$ ) tablets using the proposed HPLC methods.

\begin{tabular}{|c|c|c|c|c|c|}
\hline \multicolumn{3}{|c|}{ Dipyrone } & \multicolumn{3}{c|}{ Camylofin dihydrochloride } \\
\hline Claimed $\boldsymbol{\mu g} / \mathbf{m L}$ & Found $\boldsymbol{\mu g} / \mathbf{m L}$ & Recovery \% & Claimed $\boldsymbol{\mu g} / \mathbf{m L}$ & Found $\boldsymbol{\mu g} / \mathbf{m L}$ & $\mathbf{R e c o v e r y ~} \%$ \\
\hline 270 & 272.7 & 101 & 30 & 30.04 & 100.12 \\
\hline 225 & 224.78 & 99.90 & 25 & 24.98 & 99.94 \\
\hline 180 & 180.74 & 100.41 & 20 & 19.99 & 99.95 \\
\hline 135 & 138.58 & 102.65 & 15 & 15.20 & 101.34 \\
\hline 90 & 88.81 & 98.68 & 10 & 10.27 & 102.67 \\
\hline \multicolumn{2}{|c|}{ Mean Recovery \% } & 100.53 & \multicolumn{3}{c|}{100.80} \\
\hline
\end{tabular}

Table 11: Determination of dipyrone and camylofin dihydrochloride in pharmaceutical formulation (Spasmopyralgin $\mathrm{M}^{\circledR}$ ) tablets using the proposed HPTLC methods.

\begin{tabular}{|c|c|c|c|c|c|}
\hline \multicolumn{3}{|c|}{ Dipyrone } & \multicolumn{3}{|c|}{ Camylofin dihydrochloride } \\
\hline Claimed $\mu \mathrm{g} / \mathrm{band}$ & Found $\mu \mathrm{g} / \mathrm{band}$ & Recovery \% & Claimed $\mu \mathrm{g} / \mathrm{band}$ & Found $\mu \mathrm{g} / \mathrm{band}$ & Recovery \% \\
\hline 27 & 26.87 & 99.5 & 3 & 2.96 & 98.60 \\
\hline 31.5 & 31.19 & 99 & 3.5 & 3.45 & 98.60 \\
\hline 36 & 36.29 & 100.83 & 4 & 3.93 & 98.27 \\
\hline 40.5 & 40.96 & 101.13 & 4.5 & 4.47 & 99.30 \\
\hline 45 & 45.45 & 101 & 5 & 4.97 & 99.44 \\
\hline \multicolumn{2}{|c|}{ Mean Recovery \% } & 100.29 & \multicolumn{2}{|c|}{ Mean Recovery \% } & 98.84 \\
\hline \multicolumn{2}{|c|}{ S.D. } & 0.97 & \multicolumn{2}{|c|}{ S.D. } & 0.50 \\
\hline
\end{tabular}

Table 12: Statistical comparison between the proposed HPLC method and reported methods for the determination of dipyrone and camylofin dihydrochloride in pharmaceutical formulations (Spasmopyralgin $\mathbf{M}^{\circledR}$ ) tablets.

\begin{tabular}{|c|c|c|c|c|}
\hline \multirow{2}{*}{ Drug } & Proposed method & Reported methods & \multirow{2}{*}{ t-test } & \multirow{2}{*}{ F-test } \\
\cline { 2 - 4 } & Found (\%) \pm SD & Found $(\%) \pm$ SD & & \\
\hline Dip & $100.53 \pm 1.46$ & $99.28 \pm 0.81[6]$ & $1.67\left(2.31^{*}\right)$ & $3.24\left(6.39^{*}\right)$ \\
\hline Cam & $100.80 \pm 1.20$ & $99.47 \pm 1.02[14]$ & $1.90\left(2.31^{*}\right)$ & $1.37\left(6.39^{*}\right)$ \\
\hline
\end{tabular}

Table 13: Statistical comparison between the proposed HPTLC method and reported methods for the determination of dipyrone and camylofin dihydrochloride in pharmaceutical formulations (Spasmopyralgin $\mathbf{M}^{\circledR}$ ) tablets.

\begin{tabular}{|c|c|c|c|c|}
\hline \multirow{2}{*}{ Drug } & Proposed method & Reported methods & \multirow{2}{*}{$\boldsymbol{t}$-test } & \multirow{2}{*}{ F-test } \\
\cline { 2 - 5 } & Recovery (\%) \pm SD & Recovery (\%) \pm SD & & \\
\hline Dip & $100.29 \pm 0.97$ & $99.28 \pm 0.81[6]$ & $1.79\left(2.31^{*}\right)$ & $1.44\left(6.39^{*}\right)$ \\
\hline Cam & $98.84 \pm 0.50$ & $99.47 \pm 1.02[14]$ & $1.22\left(2.31^{*}\right)$ & $1.19\left(6.39^{*}\right)$ \\
\hline
\end{tabular}

* Tabulated $\mathrm{t}$ and $\mathrm{F}$ yalues at $95 \%$ confidence limit.

Table 14: Results of robustness of the proposed HPLC method.

\begin{tabular}{|c|c|c|c|c|}
\hline \multirow{2}{*}{ Factor } & \multicolumn{2}{|c|}{ Dipyrone } & \multicolumn{2}{c|}{ Camylofin dihydrochloride } \\
\cline { 2 - 5 } & Mean recover \% & SD & Mean recovery \% & SD \\
\hline Organic strength of mobile phase $\mathbf{\pm 1}$ & 99.17 & 1.75 & 100.19 & 1.11 \\
\hline pH of buffer $\mathbf{0 . 2}$ & 100.86 & 1.52 & 100.60 & 1.53 \\
\hline Detection wavelength $\mathbf{\pm 2}$ & 100.38 & 1.29 & 100.26 & 1.42 \\
\hline
\end{tabular}

Table 15: Results of robustness of the proposed HPTLC method

\begin{tabular}{|c|c|c|c|c|}
\hline \multirow{2}{*}{ Factor } & \multicolumn{2}{|c|}{ Dipyrone } & \multicolumn{2}{c|}{ Camylofin dihydrochloride } \\
\cline { 2 - 5 } & Mean recovery \% & SD & Mean recovery \% & SD \\
\hline Detection wavelength $\pm \mathbf{2}$ & 100.38 & 1.73 & 100.41 & 1.21 \\
\hline
\end{tabular}

\section{References}

[1]. A Jasiecka, T. Maślanka, J. Jaroszewski, Pharmacological characteristics of metamizole, Polish Journal of Veterinary Sciences, 17(1), 2014, 207-14

[2]. N W Ali, M. Gamal, M. Abdelkawy, Simultaneous determination of hyoscine butyl bromide and dipyrone in their binary mixture by RP-HPLC method, IOSR Journal of Pharmacy and Biological Sciences, 3(5), 2012, 29-36.

[3]. T S Belal, E. F. Khamis, F. A. El Yazbi and M.M.A. Hamdy, High performance liquid chromatographic determination of the ternary mixture of caffeine, dipyrone and drotaverine hydrochloride in tablets dosage form, Journal of Applied Pharmaceutical Science. 3(06), 2014, 033-039.

[4]. F F Belal, M.K. Sharaf El-Din, M.M. Tolba and H. Elmansi, Determination of two ternary mixtures for migraine treatment using HPLC method with ultra violet detection, Separation Science and Technology, 50(4), 2015. 
Comparative Study of New Hplc And Hptlc Methods For Simultaneous Determination of ....

[5]. C Chotimah, Sudjadi, S. Riyanto, A. Rohman, Simultaneous determination of metamizole, thiamin and pyridoxin in multicomponent tablet by RP-HPLC, Journal of Food and Pharmaceutical Sciences, 2(2014), 2014, 79-82.

[6]. A Salmerón-García, N. Navas, A. Martín, E. Román, J. Cabeza and L.F. Capitán-Vallvey, Determination of tramadol, metamizole, ropivacaine, and bupivacaine in analgesic mixture samples by HPLC with DAD detection, Journal of Chromatographic Science, 47(3), 2009, 231-237.

[7]. J J Lima, S.M. Oliveira Sá, J.L. Santosa and E.A. Zagatto, Multi-pumping flow system for the spectrophotometric determination of dipyrone in pharmaceutical preparations, Journal of Pharmaceutical and Biomedical Analysis, 32 (4-5), 2003, 1011-1017.

[8]. K A Sakiara, L. Pezza, C.B. Melios, H.R. Pezza, M. De Moraes, Spectrophotometric determination of dipyrone in pharmaceutical preparations by using chromotropic acid, Il Farmaco, 54(9), 1999, 629-635.

[9]. W T Suareza, O.D. Pessoa-Netob, F.C. Vicentinib, B.C. Janegitzb, R.C. Fariab and O. Fatibello-Filho, Flow injection spectrophotometric determination of dipyrone in pharmaceutical formulations using Fe(III) as reagent. Analyical Letters, 44(1-3), 2011.

[10]. N W Ali, M. Gamal, M. Abdelkawy, Simultanous determination of hyoscine butyl bromide and dipyrone in their binary mixture by RP_TLC spectrodensitometric method, International Journal of Chemical and Analytical Science, 3(10), 2012, 1578-1582.

[11]. K. Sarbhjit, K.B. S, K. Parmjit, and B. Surinder, To compare the effect of camylofin dihydrochloride (anafortin) with combination of valethamate bromide (epidosin) and hyoscine butyl-N-bormide (buscopan) on cervical dilation, Journal of Clinical and Diagnostic Research, 7(9), 2013, 1897-1899.

[12]. F A Elbarbry, M.M. Mabrouk, M.A. El-Dawy, Determination of the analgesic components of spasmomigraine tablet by liquid chromatography with ultraviolet detection, Journal of AOAC International, 90(1), 2007, 94-101.

[13]. N N Kadam, P.C. Patil, R.R. Singh, A stability indicating RP-HPLC determination of camylofin dihydrochloride in drug substance, International Journal of pharmacy and pharmaceutical Sciences, 3(3), 2011, 153-158

[14]. M V Rathnam, R.R. Singh, Simultaneous RP HPLC determination of camylofin dihydrochloride and diclofenac potassium in pharmaceutical preparations, Pharmaceutica Analytica Acta, 2010, 1:108.

[15]. R K Singh, M.V. Rathnam, S.J. Singh and R.V. Vegesna, Stability indicating method for simultaneous RP HPLC determination of camylofin dihydrochloride and nimesulide in pharmaceutical preparations, ISRN Analytical Chemistry, 2012(2012), 2011, 7.

[16]. R R Singh, M.V. Rathnam, R. Vegesna, Simultaneous RP-HPLC determination of camylofin dihydrochloride and paracetamol in pharmaceutical preparations, Trade Science Inc, 7(11), 2008, 785-788

[17]. N Patel, S.P. Acharya, N.J. Shah, A.H. Shah and D.A. Baria, Validation and application of HPLC and HPTLC-densitometry for the determination of camylofin in bulk and pharmaceutical dosage form, Inventi, 134(11), 2011.

[18]. N S Patel, V.P. Gandh, R.S. Mehta and K.K. Bhatt, Application of HPLC and HPTLC-densitometry for the simultaneous determination of camylofin and diclofenac in pharmaceutical dosage form, Der Pharmacia Lettre, 2(5), 2010, 193-207.

[19]. S Rathinam, K.S. Lakshmi, High performance thin layer chromatographic method for the simultaneous estimation of camylofin dihydrochloride and mefenemic acid in pharmaceutical tablet, International Journal of Pharmacy and Pharmaceutical Sciences, 6(1), 2014, 585-589.

[20]. Martindale" The Extra Pharmacopoeia", 31st Ed., Pharmaceutical press London, 2007.

[21]. International Conference on Harmonisation of Technical Requirements for Registration of Pharmaceuticals for Human Use, ICH Harmonised Tripartite Guideline-Validation of Analytical Procedures: Text and Methodology Q2(R1), Current Step 4 version, London, 2005

[22]. The British Pharmacopoeia, Her Majesty's Stationery Office. London,UK, 2008, pp. 404-405, 485-486, 1080-1081, 1382, 2519$2520,2559-2560,2592-2593,2766-2767,2861$. 